\title{
Documentation of Underutilized Fruit Trees (UFTs) across indigenous communities in West Java, Indonesia
}

\author{
MOCHAMMAD FIKRY PRATAMA ${ }^{1, \boldsymbol{v}}$, ANGGA DWIARTAMA ${ }^{1}$, DIAN ROSLEINE ${ }^{1}$, RIZQI ABDULHARIS ${ }^{1}$, \\ ARIFIN SURYA DWIPA IRSYAM ${ }^{2}$ \\ ${ }^{1}$ School of Life Sciences and Technology, Institut Teknologi Bandung. Jl. Ganesa No.10, Bandung 40132, West Java, Indonesia \\ Tel./fax.: +62-22-2511575. `email: fikrypratama@gmail.com \\ ${ }^{2}$ Faculty of Earth Sciences and Technology, Institut Teknologi Bandung. Jl. Ganesa No.10, Bandung 40132, West Java, Indonesia
}

Manuscript received: 2 July 2019. Revision accepted: 22 August 2019.

\begin{abstract}
Pratama MF, Dwiartama A, Rosleine D, Abdulharis R, Irsyam ASD. 2019. Documentation of Underutilized Fruit Trees (UFTs) across indigenous communities in West Java, Indonesia. Biodiversitas 20: 2603-2611. Fruit as a source of food has been mostly underrated, while in fact play a role in providing nutritional security as well as contributing to the integrity of local ecosystems. The declining significance of local indigenous fruits, often referred to as underutilized fruits, in rural populations may have an unprecedented consequence to the availability of high-quality resources for the wider society. This article, therefore, sees this importance by documenting the existence of underutilized fruit-trees across indigenous communities, often acknowledged to be the chaperones of local biodiversity. Using a combined method of interviews, exploratory observation and vegetation analysis in seven indigenous communities in West Java Province, this study investigated the role and position of fruit-tree species in their ecological landscapes and communities' knowledge systems. The article documents 75 fruit tree species, 38 out of which are categorized as underutilized. The proportion of this group of species to the total fruit tree species varied between 0 to $45 \%$. Further analysis found that the underutilized fruit trees were far smaller in abundance compared to commercial timber, fruit, and other trees. We conclude that efforts to uplift the conservation value of these fruit-trees can begin via promotion and market development by multiple stakeholders.
\end{abstract}

Keywords: Indigenous community, inventory, underutilized fruit trees, West Java

\section{INTRODUCTION}

Plants have undoubtedly been an integral part of human livelihood. In Indonesia, there are at least 30,000 species of plants, most of which are found to grow wild in forest and natural areas. Out of that number, only around 6,000 species have been utilized as food, fibre, building materials and sources of medicine. It is documented that indigenous communities in Indonesia consume in total of at least 100 species of beans and nuts, 450 species of fruits, and 250 species of vegetables and mushrooms as sources of food (Uji 2007; Walujo 2011). This article particularly focuses on fruits and fruit trees, which play an important role not only as a source of nutrition for local communities, but also form a central part in their ecosystems (Awodoyin et al. 2015; Dwiartama 2019).

Studies have documented the importance of fruits as an additional source of nutrition, including vitamins, minerals, and fibres, which altogether contribute to food security (Abu Bakar and Fry 2013; Narzary et al. 2013). This group of food sources, however, has been undervalued in terms of its significance in the narratives of food security as well as conservation. Indonesia has around 269 species of edible fruits, around $76 \%$ of which are produced by fruit trees; four known species are categorized as endangered and 19 are endemic. To this day, only 59 out of those 206 fruit tree species have been successfully cultivated in Indonesia. In the island of Java alone, around 86 fruit tree species are grown in various traditional agroforestry systems as well as found wild in remaining forests, although as high as $66 \%$ have not been cultivated commercially (Uji 2007). This group of fruit tree species is what Awodoyin et al. (2015) termed underutilized fruit trees (UFTs; see also Padulosi et al. 2013; Kour et al. 2018). UFTs are tree species which edible fruits are consumed locally, but less known in a wider geographical context. Because of its geographical relevance, what is called UFTs in one region can be commercial or known fruit trees in other regions (Padulosi et al. 2013).

The potential of these UFTs has been overshadowed by the lack of fruit consumption in Indonesian populations in general. A survey conducted by the State Statistical Agency (Badan Pusat Statistik, BPS) in 2016 showed that although $73.59 \%$ of Indonesian population do consume fruits on a regular basis, the fruit species are limited to what is known as leading commercial fruits, i.e., bananas, oranges, mangoes, rambutan, apples, salak, pawpaw, watermelons, durian, and duku (BPS Indonesia 2017). This clearly shows that there are many more of fruit potentials that have not been fully commercialized or even utilized optimally, while concurrently, these so-called underutilized fruits (UFs) have begun to disappear from local and regional markets as these markets are flooded by introduced and imported fruits (Abu Bakar and Fry 2013).

Our preliminary study in 2017 attempted to capture this reality in urban lifestyle whereby we asked respondents about their knowledge of UFs (Dwiartama, unpublished report). An online survey was made to 171 respondents on 
the basis of their knowledge about certain UFs, and the result showed that out of 50 fruits asked, only $15 \%$ were consumed regularly, $16 \%$ were known but never consumed, and a staggering $28 \%$ were unknown from the respondents. The latter included local fruits such as kupa (Syzygium polycephalum (Miq.) Merr. \& Perry), burahol (Stelechocarpus burahol (Blume) Hook.f. \& Thomson), rukam (Flacourtia rukam Zoll. \& Moritzi), menteng (Baccaurea racemosa (Reinw. ex Blume) Müll.Arg.) and bisbul (Diospyros discolor Willd.). It was also revealed that respondents between the age of 41-60 years old have at least once consumed these UFs such as kupa, whereas the respondents between 20-40 years old have not. This survey confirmed findings in other countries on the loss of knowledge about local food occurring in many societies all over the world, both in modern and indigenous settings (Kuhnlein and Receveur 1996).

Despite the sad fact that the presence of these UFs in the market economy and the society's knowledge system has been declining, the assumed abundance of UFTs in rural areas, particularly in private and community forests in the island of Java, places hope of raising the importance of UFs in both urban and rural communities (Manurung et al. 2008). One particular group of communities that is assumed to conserve these UFs in their land and knowledge system is the indigenous communities (Iskandar and Iskandar 2015). Many studies on indigenous community groups in West Java have documented the significance of their traditional agroforestry system (kebun talun) as pockets of fruit tree habitats. Underutilized fruits such as kupa (Syzygium polycephalum), pisitan and kokosan (Lansium domesticum Lansium domesticum Corrêa 'pisitankokosan group'), ceremai (Phyllanthus acidus (L.) Skeels), rukam (Flacourtia rukam), and menteng (Baccaurea racemosa) are still found, some in abundance, in these indigenous communities' local ecosystems (Rahayu and Harada 2004; Nurmalasari et al. 2012; Ramdianti et al. 2013; Iskandar and Iskandar 2015; Izzuddin and Azrianingsih 2015). As has been the case elsewhere, UFs that are managed traditionally among the indigenous people have huge potential to contribute to achieving community-based, local food security. In addition, studies have also concluded that small-scale fruit production in the mixed garden system plays an important role in maintaining the integrity of local ecologies (Christanty et al. 1986; Kuhnlein and Receveur 1996; Styger et al. 1999; Manurung et al. 2008; Jose 2009). Acknowledging indigenous communities as the chaperones of local indigenous resources, should the presence of UFTs were lost from both the communities' landscape and knowledge system, there is a huge possibility that the potentials of these UFTs also disappear from the wider society.

This article thus documents our ethnobotanical study on the utilization and management of UFTs under its local settings (Cotton 1996). Similar studies have been made in other indigenous communities around the world, although only a few have specifically focused on fruit tree species (Kuhnlein and Receveur 1996). Likewise, ethnobotanical studies on indigenous communities in West Java have been extensively made, but the majority focused on either medicinal plants, which aligns with the idea of bioprospecting, or the social and cultural aspects of plant use (Rahayu and Harada 2004; Hidayat et al. 2010; Nurmalasari et al. 2012; Ramdianti et al. 2013; Iskandar and Iskandar 2015; Izzuddin and Azrianingsih 2015). It is in the interest of this study, therefore, that documentation of UFTs is made across indigenous communities in West Java. The aims of this article were two folds: to document and describe the diversity and richness of UFT species within the local ecologies of West Java's indigenous communities and document the communities' knowledge and practices in relation to these UFTs.

\section{MATERIALS AND METHODS}

\section{Study area}

Documentation of UFTs in the communities' ecological landscapes and knowledge systems was particularly conducted in seven indigenous communities spread in West Java Province, Indonesia. These are Kampung Adat Pulo and Kampung Adat Dukuh in Garut regency, Kasepuhan Ciptagelar in Sukabumi regency, Kampung Adat Naga in Tasikmalaya regency, Kampung Adat Kuta in Ciamis regency, as well as Kampung Adat Urug and Kasepuhan Cipatat Kolot in Bogor regency (Figure 1). Data collection was conducted between July and September 2018.

Inventorization of fruit trees was done in the communities' different land uses, i.e. mixed gardens, agroforests, cemetery and around their sacred forests. In general, there are three specific landscapes in which UFTs can be found (this is also discussed extensively in Whitten et al. 1996). Firstly, backyard mixed gardens are located, as per its name, on people's backyard. This area is readily accessible and therefore utilized to grow daily spices and herbs on. People often plant some fruit trees on their backyard mixed gardens so as to also function as shade trees. Secondly, kebun-talun, or mixed traditional agroforest system, is usually located farther from dwellings and closer to natural forest areas. Here, people usually grow a mix of timber trees, fruit trees, perennial shrubs, and annual crops. Thirdly, sacred forest and landscape in and around the cemetery are often populated with a mix of wild and cultivated tree species. Some of the indigenous fruit trees can be found in this area but are not necessarily deliberately cultivated (e.g. seeds dispersed by animals). In some community groups, this area is not always accessible to regular community members.

\section{Data collection}

Data collection was made through a mix of qualitative and quantitative methods. Lists of fruit tree species were obtained from interviews using a free-listing method towards key informants (Cotton 1996). These informants were recommended by the community leaders as those that are known to be the most knowledgeable in terms of indigenous fruits. Further choice of informants was done through snowballing technique, whereas the previous key informants recommended others to be interviewed. This was done until the data reached a saturation point (no additional information was obtained during the interview). 


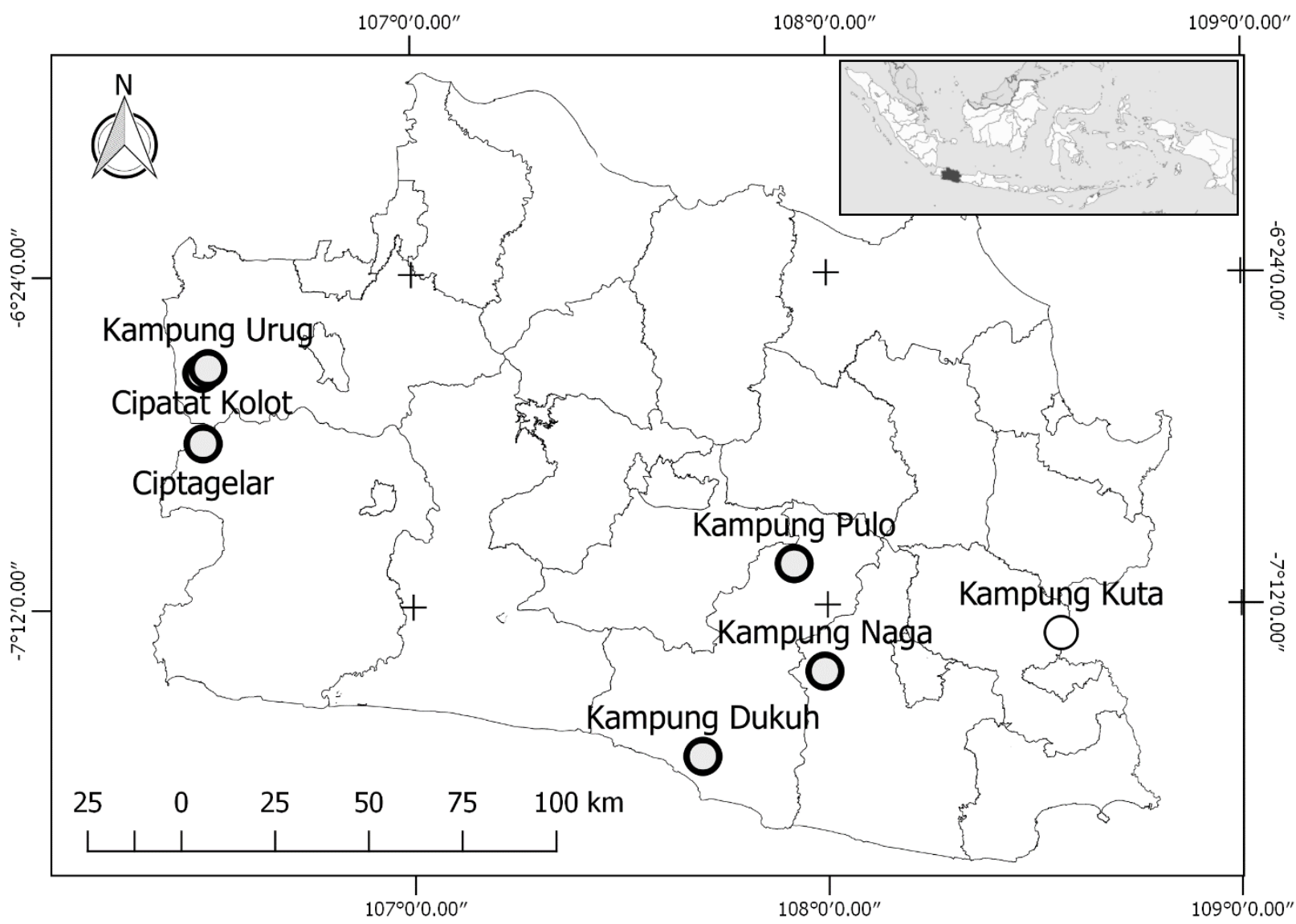

Figure 1. Distribution of the seven indigenous communities in West Java, Indonesia

Table 1. A summary of methods used for data collection

\begin{tabular}{|c|c|c|c|c|c|}
\hline \multirow{3}{*}{ Location } & \multicolumn{5}{|c|}{ Methods } \\
\hline & \multirow{2}{*}{$\begin{array}{c}\text { Interviews } \\
\text { (No. of } \\
\text { informants) }\end{array}$} & \multirow[b]{2}{*}{$\begin{array}{c}\text { Exploratory } \\
\text { (location) }\end{array}$} & \multicolumn{3}{|c|}{ Vegetation analysis } \\
\hline & & & Location & $\begin{array}{l}\text { Total } \\
\text { plots }\end{array}$ & $\begin{array}{c}\text { Total } \\
\text { size (ha) }\end{array}$ \\
\hline Cipatat & 10 & Cemetery, agroforest, backyard mixed garden & - & - & - \\
\hline Ciptagelar & 2 & Backyard mixed garden & Agroforest & 7 & 0.28 \\
\hline Dukuh & 10 & Backyard mixed garden & Forest around cemetery & 3 & 0.12 \\
\hline Kuta & 12 & Backyard mixed garden & Agroforest & 3 & 0.12 \\
\hline Naga & 1 & Agroforest, backyard mixed garden & - & - & - \\
\hline Pulo & 1 & Cemetery, agroforest, backyard mixed garden & - & - & - \\
\hline Urug & 10 & $\begin{array}{l}\text { Cemetery, agroforest, backyard mixed garden, } \\
\text { Forest area around dwelling }\end{array}$ & - & - & - \\
\hline
\end{tabular}

The list of fruit tree species was then validated through field observation qualitatively using an exploratory method in the communities' various land use. Where possible, quantitative vegetation analysis was also conducted (Omeja et al. 2004; Sutherland 2006). Vegetation analysis used a $20 \times 20 \mathrm{~m}^{2}$ quadrat plot. The largest plot was intended for big trees with diameter above $10 \mathrm{~cm}$, whereas smaller plots inside it $\left(10 \times 10 \mathrm{~m}^{2}, 5 \times 5 \mathrm{~m}^{2}\right.$ and $2 \times 2 \mathrm{~m}^{2}$ quadrat plots $)$ were used for trees with diameter between 5 and $10 \mathrm{~cm}$ (pole), trees with diameter less than $5 \mathrm{~cm}$ with more than 2 $\mathrm{m}$ height (sapling), and trees with diameter less than $5 \mathrm{~cm}$ and height less than $2 \mathrm{~m}$ (seedling), respectively. Vegetation analysis could not be conducted in all of the locations for various reasons (among others the area size, no presence of UFTs, and requests from the community leaders not to conduct any sampling activity in the some of the areas). This notwithstanding, qualitative observation was still employed in those locations where quantitative vegetation analysis was not exerted. Specimen collection was also made where necessary to be further identified in Herbarium Bandungense. Table 1 summarizes the methods used for data collection. 


\section{Data analysis}

Data collected from interview and observation were then used to make a list that shows the fruit tree species richness. The structure and floristic composition of vegetation area were analyzed by calculating the species importance value index (IVI) to show dominant tree species in each plot. The IVI was calculated from the sum of relative frequency, relative basal area, and relative density (Mueller-Dombois and Ellenberg 1974). Importance value index was calculated using the formula below.

$$
\mathrm{IVI}=\mathrm{RF}+\mathrm{RBA}+\mathrm{RD}
$$

Where;

IVI: Species importance value index

RF: Relative frequency

RBA: Relative basal area

RD: Relative density

These parameters were calculated as follows:

$$
\begin{aligned}
& \mathrm{RF}=\frac{\text { Frequencyof species-i }}{\text { Sum frequencyof allspecies }} \times 100 \% \\
& \mathrm{RBA}=\frac{\text { Basal area of Species-i }}{\text { Sum basalarea of all species }} \times 100 \% \\
& \mathrm{RD}=\frac{\text { Densityof species-i }}{\text { Sumdensity of allspecies }} \times 100 \%
\end{aligned}
$$

\section{RESULTS AND DISCUSSION}

\section{Results}

Based on the data collection, we were able to identify 75 species of fruit trees in seven indigenous communities in West Java, which include both Indonesia's native tree and introduced tree species. We limited our findings to include only those fruit tree species which fruits are able to be consumed directly without further processing. From the total of 75 species, as many as 74 species were recorded from the interviews, whereas one fruit tree species was observed in the location but was not mentioned at all by the informants; which is pomegranate (Punica granatum L.).
Furthermore, as many as 53 out of 75 species were found during the exploratory observation. This means that overall, 52 species were both mentioned during the interviews and found in the fields, and a total of 22 species were mentioned in the interviews but not found in the location. Figure 2 illustrates the intersection of species documented from interviews and exploratory observation.

The inventory result showed that fruit tree species richness across the seven indigenous communities was not equal, ranging between 18 to 41 species. Location with the highest number of fruit tree species was Kampung Adat Urug in Bogor Regency, whereas the lowest being Kampung Adat Naga in Tasikmalaya Regency. The inventory result can be seen in Table 2 .

Fruit trees documented in this study were quite varied, with 38 species $(50.67 \%)$ can be categorized as UFTs. Kampung Adat Urug was recorded to have the highest number of UFTs (17 species; $40 \%$ of its total fruit tree species). On the other hand, we did not find any UFT whatsoever in Kampung Adat Naga. The complete list of the 38 species of UFTs can be seen in Table 3. Based on that list, there were 18 species that were found in only one location, hence becomes an idiosyncratic finding. By contrast, species such as kupa gowok (Syzygium polycephalum), huni (Antidesma bunius), and teureup (Artocarpus elasticus) were found in five locations or more.

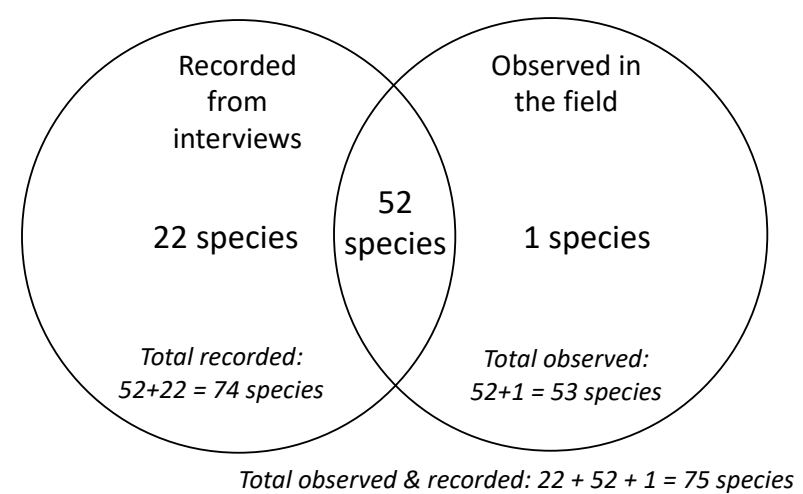

\begin{tabular}{|c|c|c|c|c|c|c|c|c|c|c|c|c|c|c|}
\hline \multirow{3}{*}{ Species } & \multicolumn{14}{|c|}{ Location } \\
\hline & \multicolumn{2}{|c|}{ Cipatat } & \multicolumn{2}{|c|}{ Ciptagelar } & \multicolumn{2}{|c|}{ Dukuh } & \multicolumn{2}{|c|}{ Kuta } & \multicolumn{2}{|c|}{ Naga } & \multicolumn{2}{|c|}{ Pulo } & \multicolumn{2}{|c|}{ Urug } \\
\hline & $\mathbf{O} *$ & $\mathbf{I}$ & $\mathbf{O}$ & $\mathbf{I}$ & $\mathbf{O}$ & $\mathbf{I}$ & $\mathbf{O}$ & $\mathbf{I}$ & $\mathbf{O}$ & $\mathbf{I}$ & $\mathbf{O}$ & $\mathbf{I}$ & $\mathbf{O}$ & I \\
\hline Annona montana Macfad. & & & + & + & & & & & & & & & & \\
\hline Annona muricata L. & + & + & & + & + & + & + & + & + & + & & & + & + \\
\hline Annona reticulata $\mathrm{L}$. & & & & & & + & & + & & & & & & \\
\hline Annona squamosa $\mathrm{L}$. & & & & & & & + & + & & & & & & \\
\hline Antidesma bunius (L.) Spreng. & + & + & & + & + & + & & + & & & + & + & & + \\
\hline Antidesma ghaesembilla Gaertn. & & & & & + & + & & + & & & & & & \\
\hline Ardisia elliptica Thunb. & & & & & & & & + & & & & & & \\
\hline Artocarpus elasticus Reinw. ex Blume & + & + & + & + & + & & & & & & + & + & + & + \\
\hline Artocarpus heterophyllus Lam. & + & + & + & + & + & + & + & + & + & + & + & + & + & + \\
\hline Artocarpus integer (Thunb.) Merr. & + & + & & & & & & & & + & & & & \\
\hline Averrhoa bilimbi L. & & & & + & & & & & & & & & & \\
\hline
\end{tabular}

Figure 2. Venn diagram showing number of fruit tree species in the communities' knowledge system and landscape

Table 2. Fruit tree species in seven indigenous communities in West Java, Indonesia 
Averrhoa carambola $\mathrm{L}$.

Baccaurea racemosa (Reinw. ex Blume) Müll.Arg.

Carica papaya $\mathrm{L}$.

Castanopsis argentea (Blume) A.DC.

Chrysophyllum cainito L.

Citrus aurantium L.

Citrus maxima (Burm.) Osbeck

Citrus reticulata Blanco

Citrus sp.

Cocos nucifera $\mathrm{L}$.

Cynometra cauliflora $\mathrm{L}$.

Dimocarpus longan Lour.

Diospyros discolor Willd.

Dracontomelon dao (Blanco) Merr. \& Rolfe

Durio zibethinus L.

Ficus racemosa $\mathrm{L}$.

Flacourtia inermis Roxb.

Flacourtia rukam Zoll. \& Moritzi

Garcinia $\times$ mangostana L.

Garcinia parviflora Benth.

Lansium domesticum Corrêa 'duku group'

Lansium domesticum Corrêa 'pisitan-kokosan group' (kokosan) Lansium domesticum Corrêa 'pisitan-kokosan group' (pisitan) Mangifera foetida Lour.

Mangifera indica $\mathrm{L}$.

Mangifera indica L. 'Bapang'

Mangifera indica L. 'Beureum Beungeut'

Mangifera indica L. 'Cengkir'

Mangifera indica L. 'Cupu'

Mangifera indica L. 'Gedong'

Mangifera indica L. 'Golek'

Mangifera indica L. 'Indramayu'

Mangifera indica L. 'Kukulu'

Mangifera indica L. 'Manalagi'

Mangifera kemanga Blume

Mangifera laurina Blume

Mangifera odorata Griff.

Mangifera sp.

Mangifera $\mathrm{sp} 2$

Manilkara zapota (L.) P. Royen

Morinda citrifolia $\mathrm{L}$.

Muntingia calabura $\mathrm{L}$.

Nephelium lappaceum $\mathrm{L}$.

Nephelium ramboutan-ake (Labill.) Leenh.

Persea americana Mill.

Phyllanthus acidus (L.) Skeels

Phyllanthus emblica L.

Pouteria campechiana (Kunth) Baehni

Psidium guajava $\mathrm{L}$.

Punica granatum $\mathrm{L}$.

Sandoricum koetjape (Burm.f.) Merr.

Spondias dulcis Parkinson

Stelechocarpus burahol (Blume) Hook.f. \& Thomson

Syzigium sp.

Syzygium aqueum (Burm.f.) Alston

Syzygium cumini (L.) Skeels

Syzygium malaccense (L.) Merr. \& L.M. Perry

Syzygium polycephaloides (C.B. Rob.) Merr.

Syzygium polycephalum (Miq.) Merr. \& L.M. Perry

Syzygium pycnanthum Merr. \& L.M. Perry

Syzygium samarangense (Blume) Merr. \& L.M. Perry

Tamarindus indica $\mathrm{L}$.

Theobroma cacao L.

Xerospermum noronhianum Blume

Sum

Total

Note: *) Note: $\mathrm{O}=$ Observed in the field; $\mathrm{I}=$ Recorded during the interviews
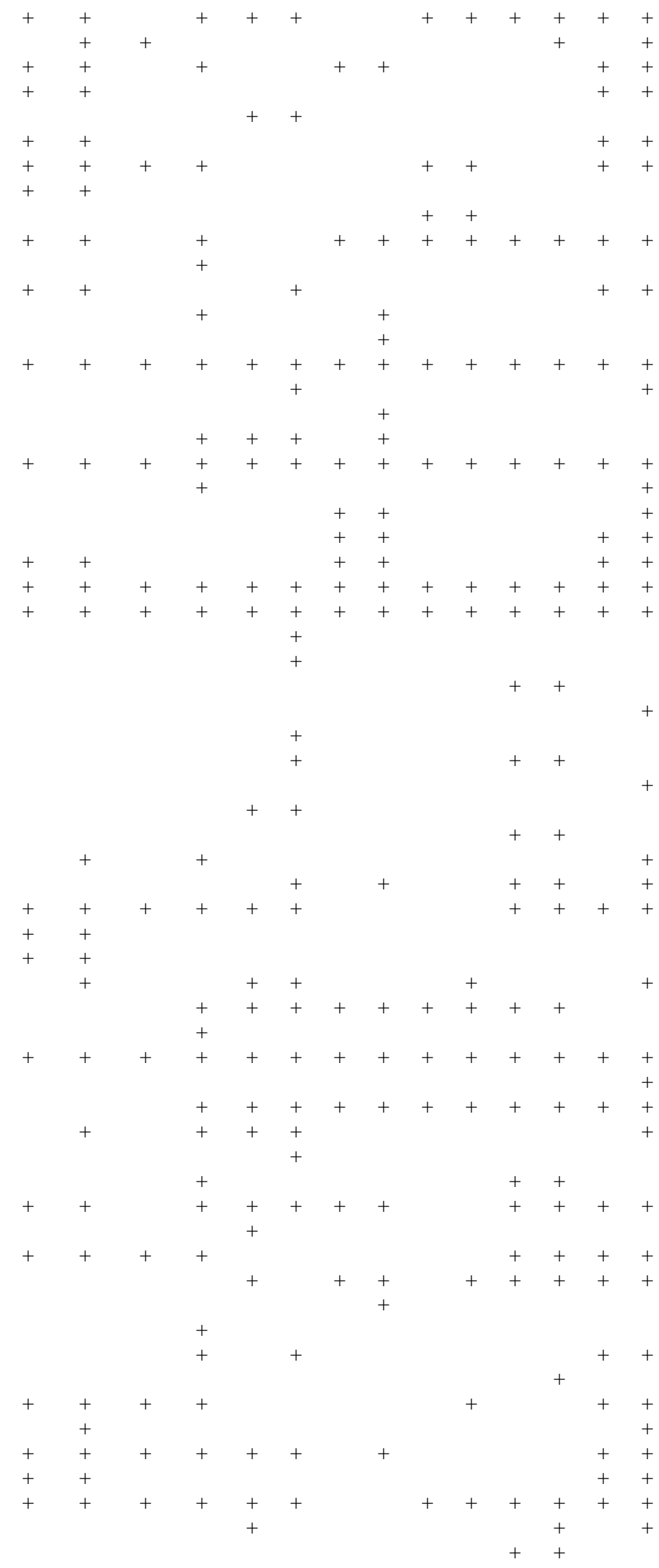

$\begin{array}{llllllllllllll}28 & 33 & 15 & 33 & 25 & 31 & 18 & 29 & 14 & 18 & 23 & 26 & 27 & 41\end{array}$ $35 \quad 29$ 18 26 41 
Table 3. List of UFT species along with their location of findings

\begin{tabular}{|c|c|c|c|c|c|c|c|c|c|}
\hline \multirow[b]{2}{*}{ Species } & \multirow[b]{2}{*}{ Vernacular name } & \multicolumn{7}{|c|}{ Location } & \multirow[b]{2}{*}{ Freq. } \\
\hline & & 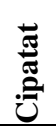 & 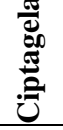 & $\frac{\underline{z}}{\bar{z}}$ & $\underset{\Xi}{\mathbb{3}}$ & 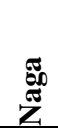 & 을 & $\stackrel{0}{0}$ & \\
\hline Annona montana Macfad. & Nona & & + & & & & & & 1 \\
\hline Annona reticulata $\mathrm{L}$. & Manoa/Nona & & & + & + & & & & 2 \\
\hline Annona squamosa L. & Srikaya & & & & + & & & & 1 \\
\hline Antidesma bunius (L.) Spreng. & Huni/Seueur & + & + & + & + & & + & + & 6 \\
\hline Antidesma ghaesembilla Gaertn. & Onyam & & & + & + & & & & 2 \\
\hline Ardisia elliptica Thunb. & Lampeni & & & & + & & & & 1 \\
\hline Artocarpus elasticus Reinw. ex Blume & Teureup & + & + & + & & & + & + & 5 \\
\hline Baccaurea racemosa (Reinw. ex Blume) Müll.Arg. & Menteng/Bencoy & + & + & & & & + & + & 4 \\
\hline Castanopsis argentea (Blume) A.DC. & Saninten & + & & & & & & + & 2 \\
\hline Chrysophyllum cainito L. & Sawo hejo & & & + & & & & & 1 \\
\hline Cynometra cauliflora $\mathrm{L}$. & Namnam & & + & & & & & & 1 \\
\hline Diospyros discolor Willd. & Bisbul & & + & & + & & & & 2 \\
\hline Dracontomelon dao (Blanco) Merr. \& Rolfe & Dahu & & & & + & & & & 1 \\
\hline Ficus racemosa $\mathrm{L}$. & Loa/kondang & & & + & & & & + & 2 \\
\hline Flacourtia inermis Roxb. & Lobi lobi & & & & + & & & & 1 \\
\hline Flacourtia rukam Zoll. \& Moritzi & Rukam/Kupa landak & & + & + & + & & & & 3 \\
\hline Garcinia parviflora Benth. & Ceuri & & + & & & & & + & 2 \\
\hline Lansium domesticum Corrêa 'pisitan-kokosan group' & Kokosan & & & & + & & & + & 2 \\
\hline Lansium domesticum Corrêa 'pisitan-kokosan group' & Pisitan & + & & & + & & & + & 3 \\
\hline Mangifera indica L. 'Bapang' & Mangga bapang & & & + & & & & & 1 \\
\hline Mangifera indica L. 'Beureum Beungeut' & Mangga beureum beungeut & & & + & & & & & 1 \\
\hline Mangifera indica L. 'Cupu' & Mangga cupu & & & & & & & + & 1 \\
\hline Mangifera indica L. 'Kukulu' & Mangga kukulu & & & + & & & & & 1 \\
\hline Mangifera kemanga Blume & Kemang & + & + & & & & & + & 3 \\
\hline Mangifera laurina Blume & Pari/Mangga piit & & & + & + & & + & + & 4 \\
\hline Mangifera sp. & Gandarasa & + & & & & & & & 1 \\
\hline Mangifera $\mathrm{sp} 2$ & Binglu & + & & & & & & & 1 \\
\hline Nephelium ramboutan-ake (Labill.) Leenh. & Kapulasan & & & & & & & + & 1 \\
\hline Phyllanthus acidus (L.) Skeels & Cereme & + & + & + & & & & + & 4 \\
\hline Phyllanthus emblica $\mathrm{L}$. & Malaka & & & + & & & & & 1 \\
\hline Pouteria campechiana (Kunth) Baehni & Sawo mentega & & + & & & & + & & 2 \\
\hline Sandoricum koetjape (Burm.f.) Merr. & Kecapi & + & + & & & & + & + & 4 \\
\hline Stelechocarpus burahol (Blume) Hook.f. \& Thomson & Burahol & & & & + & & & & 1 \\
\hline Syzygium cumini (L.) Skeels & Jamblang & & & & & & + & & 1 \\
\hline Syzygium polycephaloides (C.B. Rob.) Merr. & Kupa piit & + & & & & & & + & 2 \\
\hline Syzygium polycephalum (Miq.) Merr. \& L.M. Perry & Kupa gowok & + & + & + & + & & & + & 5 \\
\hline Syzygium pycnanthum Merr. \& L.M. Perry & Kopo & + & & & & & & + & 2 \\
\hline Xerospermum noronhianum Blume & Tundun & & & & + & & & & 1 \\
\hline Total UFTs & & 13 & 13 & 14 & 15 & 0 & 7 & 17 & \\
\hline Total species of fruit trees & & 33 & 34 & 35 & 29 & 18 & 26 & 41 & \\
\hline
\end{tabular}

Vegetation conditions in some of the indigenous communities' local environments can to some extent provide a snapshot of the typical vegetation area of rural indigenous in West Java. Due to local circumstances, quantitative vegetation analysis data were only taken from Kasepuhan Ciptagelar, Kampung Adat Dukuh, and Kampung Adat Kuta. In other locations, the rationale for not conducting quantitative vegetation analysis was as follows. In Kampung Pulo, due to a reasonably small area, qualitative exploratory observation is sufficient to build a snapshot of fruit tree distribution. In Kampung Naga, there were no documented UFTs from either the interviews and exploratory observation, thus vegetation analysis is not necessary. In Kampung Urug and Kasepuhan Cipatat
Kolot, we appreciate the community leaders' request not to conduct any sampling and research activities in their sacred forest around cemetery, in which UFTs are mostly found. In those four locations, qualitative exploratory observation was allowed and therefore conducted to complement the data.

In general, the vegetation areas consisted of timber trees and fruit trees in various proportions. Based on importance value index (IVI), the dominant trees, however, were mainly timber species such as teak (Tectona grandis), manii (Maesopsis eminii), and albasiah (Falcataria moluccana) and tree species of spices such as cloves and bay leaf (Syzygium polyanthum). Fruit trees were also present, but mostly dominated by commercial fruit trees, 
such as durian (Durio zibethinus), jackfruit (Artocarpus heterophyllus), mangosteen (Garcinia $x$ mangostana), soursop (Annona muricate) and coconuts (Cocos nucifera). UFTs, as a consequence, exist in a very low dominance.

In Kasepuhan Ciptagelar, large trees (above $10 \mathrm{~cm}$ in trunk diameter) dominate the forest, but an extent of smaller individual trees indicate a good regeneration of the forest. In the agroforest system (kebun talun), we found 11 fruit tree species, six of which are UFTs. In addition to commercial fruit trees such as jackfruit, grapefruit, mango and avocado, UFTs such as nona (Annona montana), teureup (Artocarpus elasticus), menteng (Baccaurea racemosa), beunying (Ficus fistulosa), and kecapi (Sandoricum koetjapi) were also found, even though in a very rare distribution and low density. Some dominant species with high IVI in Kasepuhan Ciptagelar's agroforest were cloves (Syzygium aromaticum), sugar palm (Arenga pinnata), jackfruit (Artocarpus heterophyllus), durian (Durio zibethinus), and manii (Maesopsis eminii); none of which are UFTs. The same holds true with the smaller trees, with durian, mango, mangosteen, and other timber trees dominating the landscape. Coffee trees also dominated the understorey, also it seems that the trees were only recently grown. One interesting finding was beunying (Ficus fistulosa), a type of UFT that is relatively dominant at a smaller life form (seedling), despite its wild state. Beunying is known to be a source of feed for birds and primates, and so its significance in the ecosystem is unlikely due to the community's effort to cultivate it.

Vegetation analysis in Kampung Adat Dukuh was conducted in the existing sacred forest, covering a total of 0.12 hectares area. We found 26 tree species, including fruit trees such as limus (Mangifera foetida) and kaweni (Mangifera odorata), as well as three UFTs: teureup (Artocarpus elasticus), rukam (Flacourtia rukam), and mangga kukulu (Mangifera indica L.'Kukulu'). Mangga kukulu is a variety of mango which fruit looks ovate compared to the typical mango fruit, as well as darker/dark purple skin when ripe.

Notwithstanding this richness of fruit trees, the dominant species of tree in Kampung Adat Dukuh was teak (Tectona grandis) in every level of size. This indicates the inhabitants' preference for commercial timber tree over unmarketable fruit trees. Furthermore, unlike other villages, there were fewer plots of agroforest found in Kampung Adat Dukuh, demonstrating their preference for paddy fields, dwellings and monoculture fields dominated by cloves and a species of dark-skinned bamboo (Gigantochloa atroviolacea).

Vegetation analysis in Kampung Adat Kuta in Ciamis region was conducted in coverage of 0.12 hectares of agroforest land consisting of three plots. We found 23 species of trees, with 11 species were fruit trees, albeit commercial ones (coconuts, mangosteen, soursop, jackfruit, pawpaw, and others). Three species are categorized as UFTs, which are kokosan and pisitan (Lansium domesticum Corrêa 'pisitan-kokosan group'), and tundun (Xerospermum noronhianum). Tundun is a form of wild rambutan with a sour refreshing taste. The dominant tree species are a combination of timber (Falcataria moluccana) and commercial fruit (coconut) trees. Coconut dominates the agroforest structures with a density of around 175 individuals ha $^{-1}$. Pisitan is the only UFT to be recorded within the five species dominating the landscape in every level of size. It even has a higher density than commercial timber trees such as $F$. moluccana and tisuk (Hibiscus macrophyllus) or other commercial fruit trees.

\section{Discussion}

\section{Situating UFTs within the indigenous communities' priorities}

The structure and composition of vegetation in the seven indigenous communities in this study are made of a mixture of fruit trees and other trees. Commercial fruit trees like jackfruit, durian, mangosteen, rambutan, and coconut were found in abundance quite equally in the seven communities. Those three species are planted and cultivated deliberately to be used either subsistence for individual uses or shared with relatives and neighbors. Only during a plentiful harvest does the owner sell the surpluses to the local market for addition of their earnings. Those are fruits with a preferable taste according to their subjective judgment (and strengthened by existing market demand), and thus have higher economic potential.

By contrast, there was no UFT deliberately cultivated by the communities except for pisitan and kokosan in Kampung Adat Kuta. The UFTs found during exploratory observations were those that grow naturally and are not cut down for their timber. Even though the informants agreed that the fruits also have a good taste profile, they are not drawn to cultivate and maintain the trees because there is no market potential for these fruits. It was revealed that timber becomes the main driver towards agroforest maintenance. Not only is the timber used for building materials, but it is also used as fuel for cooking. When people are in need of an urgent wood to chop, their priority would be those with no economic potential, and therefore people often utilize UFT as a source of low-quality timber. In addition, timber tree species has a wide market acceptance and is easier to sell as a valued source of income, which caused UFTs to be cut down to provide space for commercial timber tree species. This has caused a decline in UFT's population. Younger generations are even more oblivious to UFs. Children prefer introduced fruits and processed foods, bought in the local kiosks, because they taste better and are easier to obtain.

Other commercial trees also exist as part of the forest structure. Among others, cloves (Syzygium aromaticum) and sugar palm (Arenga pinnata) have higher economic value than fruit trees, sometimes competing with timber trees in terms of importance. Clove trees are grown for their flower buds, which are sold at a relatively high price after being sun-dried. This value has made cloves among the dominant trees in Kampung Adat Dukuh and Kasepuhan Ciptagelar. Sugar palm, on the other hand, has both economic and cultural significances, due to its multifunctionality as a source of palm sugar, processed fruit, and its leaves to be used as roof material.

It can, therefore, be concluded that the dominant trees grown in the indigenous communities need to have at least 
one of the requirements: they have either a certain market value (can be sold in the market through an established distribution channel), social value (they taste good, preferable, or have a utility value), or cultural value (they just too important to be cut down). Generally speaking, the priorities for planting, growing and managing trees in the community's available landscape are as follows: (i) timber trees, (ii) other commercial trees, and lastly (iii) fruit trees, with UFTs being at the bottom of the priority list. The only reason for these UFTs to exist is that they grow naturally in wild and have not been seen as a competitor to the commercial tree species.

It is important to note here that despite the declining importance of UFTs, there is still a strong value among the community groups to protect and maintain forests as a source of intangible benefits, including clean and continuous water supply, fresh air, and most importantly in keeping their ancestors (that are said to be living in the sacred forest) safeguarding the villages from harmful disasters. This has undoubtedly brought a positive impact on the wider natural forest ecosystem and the ecological integrity of the wider landscape. This notwithstanding, UFTs have never been part of the conservation equation. As also documented elsewhere (Moran et al. 2001; Cotton 1996), conservation approach on the basis of the integrity of ecosystem, as employed by many traditional communities, has a somewhat different take compared to a modern conservation approach that focuses on the usevalue of biodiversity. While forest conservation approach as employed by the indigenous communities through their revered sacred forest is effective in conserving the biodiversity inside that particular sacred forest (without the community know what is even inside it), the existence of species outside of that boundary, including UFTs, can in fact be threatened by the blindspot provided by this approach. One of the highlights of our finding, therefore, is that while natural forest as an integrated landscape is left intact, UFTs and another biodiversity that goes beyond that cultural boundary is not.

\section{Opening market access for UFTs}

Considering the declining number of UFT population and the rationale behind this decline, there is a strong and urgent need to build a market for UFs, either in the regional markets or in their local settings. From our study, we have found that some of the fruits (e.g. huni, kupa gowok, pisitan and kokosan) are sold occasionally in the local market, albeit in relatively lower prices compared to the commercial fruits. For example, huni (Antidesma bunius) were sold locally for Rp.8,000 per kilogram (equal to 60 US cents), whereas commercial fruits such as durian could be sold for twice or three times the price of huni. This is also in contrast with our follow up study on regional markets that sell huni for seven times the price (Rp.76,000 per kilogram). The same holds true for kupa gowok (Syzygium polycephalum), which was sold in the online market for four times the local price. Furthermore, other UFs such as cereme, kecapi, kemang, lobi lobi, malaka, rukam, namnam, and menteng were also marketed in online and regional markets as exclusive fruits with relatively high prices, yet are in fact never sold in the seven community groups that we studied. This indicates two states. First, that despite being unpopular and underutilized in their local settings, some local fruits may have better economic values in the urban society, due among others to the growing interests of urbanites to experience new sources of food. Second, this finding also indicates that indigenous community groups may not necessarily be the main source of UFs. Other rural communities that are not bound by indigeneity can, in fact, provide a reasonable amount of UFs, so long as they are well connected to markets.

The newly established market system for UFs, along with the existing traditional markets at the local level, shows that there is a potential to create a conservation pathway for UFT species through market mechanisms. By increasing the demand for UFTs in the external market, community awareness, interest, and participation to conserve this biodiversity can also be improved. Development of a market mechanism that can equally act as a knowledge-sharing platform between indigenous communities and urban citizens, particularly through a fair system, thus becomes a necessary prerequisite. It is not easy to create a market system for UFs, considering their already declining population and significance. Our further research, therefore, aims to understand UFs from the demand side, observing the small, albeit growing, interests of urban citizens to explore unique food sources. This study, and the results of the documentation, in particular, has the aim to reach a wider audience so as to promote a novel source of food and nutrition for both the rural and urban communities.

In conclusion, this article has documented the species richness and abundance of underutilized fruit trees (UFTs) in their local ecologies among and across seven indigenous communities in West Java, which can be considered wealth in both knowledge system as well as landscape system contexts. This study has also found that the benefit to identify, curate and manage UFTs as potential resources go far not only for the community's nutritional, economic and social benefits, but also for the integrity of their local ecologies due to the fact that these UFTs have been an integral part of their agroforest structure and composition. This study has revealed a sad fact that UFTs are no longer a significant part of the indigenous community. There are two possible ways of seeing this. One, that UFTs are unavoidably declining as occurs anywhere else. Two, that perhaps we put the assumption wrong; that the sources of UFTs are in fact not (necessarily) the indigenous community, and so the tree species are possibly conserved and utilized in other pockets of rural communities.

That regardless, we do concur that indigenous community has a particular traditional food system that involves various resources available at their disposal. This traditional food system also includes plant and animal resources, both cultivated or grow wild, as sources of nutrition (Kuhnlein and Receveur 1996). Many studies have shown that these resources, including fruits, can be a better source of nutrition for indigenous communities, as opposed to what they are now facing (Burlingame 2000). It is only logical that we need to reverse the demise of UFTs 
by once again uplifting the economic, social and/or cultural values of the UFTs for the communities, i.e. reversing them from being underutilized. When the driving factor comes in the form of external dynamics (market demand, changing urban lifestyle), then the value of UFTs must also come from these external factors, or at least partially.

One of the few ways to conserve the presence of UFTs is by repositioning traditional and rural community groups as chaperones of biodiversity, such that has been the core argument in the Convention of Biological Diversity (CBD) and its derivative (Moran et al. 2001). Further advancement in scientific data on nutritional value of UFs and its embedded benefits will add to this documentation study, and altogether contribute to the improvement of value of UFTs. Knowledge and resources that are safeguarded by indigenous communities need to be mutually protected, codified, and promoted through the involvement of multiple stakeholders, including the government, civil society, private sectors, and the academic community (Kuhnlein 2003).

\section{ACKNOWLEDGEMENTS}

This study was funded by Indonesia's Ministry of Research, Technology and Higher Education under the PDUPT research scheme (Contract Number: 127/SP2H/PTNBH/DRPM/2018). We would like to thank the seven indigenous community groups for their involvement in the Project, as well as the anonymous reviewer for his/her valuable comments and insights on the earlier version of this article.

\section{REFERENCES}

Abu Bakar MF, Fry JR. 2013. A review on underutilized indigenous bambangan (Mangifera pajang) fruit as a potential novel source for funtional food and medicine. J Med Plants Res 7 (45): 3292-3297.

Awodoyin RO, Olubode OS, Ogbu JU, Balogun RB, Nwawuisi JU, Orji KO. 2015. Indigenous fruit trees of Tropical Africa: status, opportunity for development and biodiversity management. Agric Sci 6: $31-41$.

BPS Indonesia. 2017. Konsumsi buah dan sayur susenas Maret 2016. http://gizi.depkes.go.id/wp-content/uploads/2017/01/Paparan-BPSKonsumsi-Buah-Dan-Sayur.pdf. 23 October 2018. [Indonesian]

Burlingame B. 2000. Wild nutrition. J Food Composition 13: 99-100.

Christanty L, Abdoellah OS, Marten GG, Iskandar J. 1986. Traditional agroforestry on West Java: the pekarangan (homegarden) and kebuntalun (annual-perennial rotation) cropping systems. In: Marten GG (eds) Traditional Agriculture in Southeast Asia: A Human Ecology Perspective. Westview Press, Colorado.

Cotton CM. 1996. Ethnobotany: Principles and Applications. John Wiley \& Sons, Chichester.
Mueller-Dombois MD, Ellenberg H. 1974. Aims \& Methods of Vegetation Ecology. Wiley \& Sons, New York.

Dwiartama A. 2019. Indigenous food systems. In: Duncan J, Carolan M, Wiskerke $\mathrm{H}$ (eds.) Routledge Handbook of Sustainable and Regenerative Food Systems. Routledge, Abingdon.

Hidayat S, Hikmat A, Zuhud EA. 2010. Kajian etnobotani masyarakat Kampung Adat Dukuh Kabupaten Garut, Jawa Barat. Media Konservasi 15 (3): 139-151. [Indonesian]

Iskandar J, Iskandar BS. 2015. Studi etnobotani keanekaragaman tanaman pangan pada sistem huma dalam menunjang kemanan pangan orang Baduy. Pros Semnas Masy Biodiv Indon 1 (6): 1265-1272. [Indonesian]

Izzuddin MQ, Azrianingsih R. 2015. Inventarisasi tumbuhan obat di Kampung Adat Urug, Desa Urug, Kecamatan Sukajaya, Kabupaten Bogor. Natural B 3 (1): 81-92. [Indonesian]

Jose S. 2009. Agroforestry for ecosystem services and environmental benefits: an overview. Agrofor Syst 76: 1-10.

Kour S, Bakhsi P, Sharma A, Wali VK, Jasrotia A, Kumari S. 2018. Strategies on conservation, improvement and utilization of underutilized fruit crops. Intl J Curr Microbiol Appl Sci 7 (3): 638650.

Kuhnlein HV. 2003. Micronutrient nutrition and traditional food systems of indigenous peoples. Food Nutr Agric 32: 33-39.

Kuhnlein HV, Receveur O. 1996. Dietary change and traditional food systems of indigenous people. Ann Rev Nutr 16: 417-442.

Manurung GE, Roshekto JM, Budidarsono S, Kurniawan I. 2008. Chapter 4 Dudukuhan tree farming systems in West Java: How to mobilize self-strengthening of community-based forest management? In: Snelder DJ, Lasco DL (eds) Smallholder Tree Growing for Rural Development and Environmental Services. Springer, Netherlands

Moran, Katy, King, SR, Carlson TJ. 2001. Biodiversity prospecting: lessons and prospects. Ann Rev Anthropol 30: 505-526.

Narzary H, Brahma S, Basumatary S. 2013. Wild edible fruits of Kokrajhar district of Assam, North-East India. Asian J Plant Sci Res 3 (6): 95-100.

Nurmalasari N, Sukarsa Hidayah HA. 2012. Studi kasus pemanfaatan tumbuhan sebagai obat-obatan tradisional oleh masyarakat adat Kampung Naga di Kabupaten Tasikmalaya. Biosfera 29 (3): 141-150. [Indonesian]

Omeja P, Obua J, Cunningham A. 2004. Regeneration, density and size class distribution of tree species used for drum making in central Uganda. African J Ecol 42: 129 - 136.

Padulosi S, Thompson J, Rudebjer P. 2013. Fighting Poverty, Hunger and Malnutrition with Neglected and Underutilized Species (NUS): Needs, Challenges and the Way Forward. Bioversity International, Rome.

Rahayu M, Harada K. 2004. Peran tumbuhan dalam kehidupan tradisional masyarakat di Taman Nasional Gunung Halimun Jawa Barat. Berita Biologi 7 (1): 17-23. [Indonesian]

Ramdianti N, Hidayah HA, Widiawati Y. 2013. Kajian etnobotani masyarakat adat Kampung Pulo di Kabupaten Garut. Biosfera 30 (1): 1-13. [Indonesian]

Styger E, Rakotoarimanana J, Rabevohitra R, Fernandes E. 1999. Indigenous fuit trees of Madagascar: potential components of agroforestry systems to improve human nutrition and restore biological diversity. Agrofor Syst 46: 289-310.

Sutherland WJ. 2006. Ecological Census Techniques a handbook. Cambridge University Press, New York.

Uji T. 2007. Review: Keanekaragaman jenis buah-buahan asli Indonesia dan Potensinya. Biodiversitas 8 (2): 157-167. [Indonesian]

Walujo EB. 2011. Keanekaragaman hayati untuk pangan. http://www.opi.lipi.go.id/data/1228964432/data/13086710321320841 770.makalah.pdf. 21 October 2018. [Indonesian]

Whitten AJ, Soeriaatmadja RS, Afiff SA. 1996. Ecology of Java \& Bali Vol. 2. Oxford University Press, Oxford. 